\title{
UNITARY v. PLURAL CONCEPTION OF ANTILIPID ANTIBODY IN SYPHILITIC SERUM*
}

\author{
BY \\ AMAL KUMAR MITRA, SUNIL KUMAR BISWAS, SUKUMAR SEN, \\ and NARAYAN CHANDRA BHATTACHARJEE
}

\section{V.D. Research Department, Government of West Bengal, Calcutta}

The conception of complement-fixing antibody put forward by Ehrlich $(1898,1900)$ is that it has two receptors (one cytophilic and one complementophilic) and that the reaction between the antigen and antibody is not complete until complement has acted upon them. According to him this complement-fixing antibody is a receptor of the third order, and, as such, differs from other antibodies, such as agglutinins and precipitins. Bordet (1898), on the other hand, believed that complement acted on the antigen-antibody complex and not on one alone or in succession, and that the complement was not essential for the antigen-antibody union, since it only produced lysis (in the haemolytic system) of an already sensitized cell.

This unitary conception of antibody, as well as its plurality of action or manifestation (Bail and Hoke, 1908 ; Dean, 1917 ; Zinsser, 1921 ; Nicolle and Césari, 1922; Marrack, 1938), has already gained almost universal acceptance. If it is true of other antigen-antibody systems, it should also be true in diagnostic syphilitic serology-in the lipid antigen-reagin system-provided this be a true antigen-antibody system.

Eagle (1935) showed that the reaction between the lipid antigen and the syphilitic reagin was in the nature of a true antigen-antibody reaction; and that the two methods-complement fixation and flocculation-were only different indicators for the same substance (Eagle and Hogan, 1940).

In spite of so much evidence, Rein (1950), and Rein and Kostant (1949), dealing with the diagnostic and therapeutic problems of syphilis, gave the opinion (as an analogue to the monovalent antibody, detected in Rh-incompatible mothers and their children by Landsteiner and Wiener, 1940) that the complement-fixing antilipid antibody in syphilitic sera differed from the flocculating antibody. The former was univalent whilst the latter was bivalent. The globulin component of the monovalent antibody, being a smaller molecule than that of the bivalent one, could easily pass through

* Received for publication April 20, 1953. the placental membrane, and was thus responsible for the high percentage of positive complementfixation reactions detected amongst children from syphilitic mothers, though the children themselves were not syphilitic subjects. More recently, Puccinelli (1952) has also expressed views in favour of the existence of a different antilipid-antibody component for each of the complement-fixation and flocculation reactions used in sero-diagnosis.

\section{Present Investigation}

The intention of our work was to investigate the difference between the unitary and plural conceptions of antilipid antibody in syphilitic serum, and also to determine which of the two concepts is correct.

Material and Method.-Positive and negative sera were obtained from known syphilitic and non-syphilitic subjects from the V.D. treatment centre in the Medical College Hospital, Calcutta. Positivity or negativity were first confirmed by standard methods-Kahn Standard Test, V.D.R.L. Slide Test, and Complement-Fixation Test (M.R.C. No. 14). Only the frankly positive and frankly negative sera were selected for our experiments. These sera were then subjected to absorption by lipid antigen, as was done by Eagle (1935), but in a different and more elaborate way (see below), and were finally tested for reagin activity by different standard methods for the S.T.S. The total numbers of sera tested in the three parts of the experiment are shown in Table $I$.

TABLE I

NUMBERS OF SERA TESTED BY EXPERIMENT (PARTS I, II, AND III)

\begin{tabular}{|c|c|c|c|c|c|c|}
\hline \multirow{2}{*}{\multicolumn{5}{|c|}{ Experiment }} & \multicolumn{2}{|c|}{ Number of Sera } \\
\hline & & & & & \multirow{2}{*}{$\begin{array}{c}\text { Syphilitic } \\
30 \\
5 \\
15\end{array}$} & \multirow{2}{*}{$\begin{array}{r}\text { Non-syphilitic } \\
30 \\
5 \\
15\end{array}$} \\
\hline *Part I & & $\begin{array}{l}\text { uup } \\
\text { up } \\
\text { up }\end{array}$ & $\because$ & $\begin{array}{l}\because \\
\therefore\end{array}$ & & \\
\hline *Part II & . & . & .. & . & 5 & 5 \\
\hline${ }^{*}$ Part III & . & . & .. & . & 3 & 3 \\
\hline \multicolumn{2}{|c|}{ Total } & . & .. & . & 58 & 58 \\
\hline \multicolumn{5}{|c|}{ Total syphilitic and non-syphilitic } & \multicolumn{2}{|c|}{116} \\
\hline
\end{tabular}

*A control test with 0.9 per cent. saline was also performed with each experiment. 
TABLE II

RESULTS OF EXPERIMENT (PART I)

\begin{tabular}{|c|c|c|c|c|c|c|c|c|c|c|c|c|}
\hline & \multicolumn{2}{|l|}{ Group } & \multicolumn{2}{|c|}{$\begin{array}{l}\text { Antigen-Serum- } \\
\text { Saline Mixture }\end{array}$} & \multicolumn{2}{|c|}{$\begin{array}{l}\text { Supernatant } \\
\text { Fluid }\end{array}$} & \multicolumn{2}{|c|}{$\begin{array}{l}\text { S.F. }+ \text { W.R. } \\
\text { Antigen }\end{array}$} & \multicolumn{2}{|c|}{ Filtration } & \multicolumn{2}{|c|}{$\begin{array}{c}\text { Filtration }+ \text { W.R } \\
\text { Antigen }\end{array}$} \\
\hline & & & 3 MHD & 5 MHD & 3 MHD & $5 \mathrm{MHD}$ & 3 MHD & 5 MHD & 3 MHD & 5 MHD & $3 \mathrm{MHD}$ & 5 MHD \\
\hline \multirow{6}{*}{$\underset{\text { tested }}{\text { A. Kahn }}$} & \multirow{2}{*}{ Positive Serum } & (1) & NH & $\mathrm{NH}$ & $\begin{array}{c}\text { NH or } \\
\text { TH }\end{array}$ & $\begin{array}{c}\mathrm{H} \text { or } \mathrm{T} \\
\text { cell }\end{array}$ & $\begin{array}{c}\text { NH or } \\
\text { TH }\end{array}$ & $\begin{array}{c}\mathrm{H} \text { or } \mathrm{T} \\
\text { cell }\end{array}$ & $\mathbf{H}$ & $\mathbf{H}$ & $\mathbf{H}$ & $\mathbf{H}$ \\
\hline & & $\overline{(2)}$ & NH & NH & $\underset{\mathrm{TH}}{\mathrm{NH} \text { or }}$ & $\begin{array}{c}\mathrm{H} \text { or } \mathrm{T} \\
\text { cell }\end{array}$ & $\underset{\mathrm{TH}}{\mathrm{NH} \text { or }}$ & $\begin{array}{c}\mathrm{H} \text { or } \mathrm{T} \\
\text { cell }\end{array}$ & $\mathbf{H}$ & $\mathbf{H}$ & $\mathbf{H}$ & $\mathbf{H}$ \\
\hline & \multirow{2}{*}{$\begin{array}{l}\text { Negative Serum (antigen } \\
\text { serum ratio same as in } \\
\text { positive serum) }\end{array}$} & (1) & $\mathbf{H}$ & $\mathbf{H}$ & $\mathbf{H}$ & $\mathbf{H}$ & $\mathbf{H}$ & $\mathbf{H}$ & $\mathbf{H}$ & $\mathbf{H}$ & $\mathbf{H}$ & $\mathbf{H}$ \\
\hline & & (2) & $\mathbf{H}$ & $\mathbf{H}$ & $\mathbf{H}$ & $\mathbf{H}$ & $\mathbf{H}$ & $\mathbf{H}$ & $\mathbf{H}$ & $\mathbf{H}$ & $\mathbf{H}$ & $\mathbf{H}$ \\
\hline & \multirow{2}{*}{$\begin{array}{l}0.9 \text { per cent. Saline (anti- } \\
\text { gen saline ratio same as } \\
\text { in positive serum) }\end{array}$} & (1) & $\mathbf{H}$ & $\mathbf{H}$ & $\mathbf{H}$ & $\mathbf{H}$ & $\mathbf{H}$ & $\mathbf{H}$ & $\mathbf{H}$ & $\mathbf{H}$ & $\mathbf{H}$ & $\mathbf{H}$ \\
\hline & & $\overline{(2)}$ & $\mathbf{H}$ & $\mathbf{H}$ & $\mathbf{H}$ & $\mathbf{H}$ & $\mathbf{H}$ & $\mathbf{H}$ & $\mathbf{H}$ & $\mathbf{H}$ & $\mathbf{H}$ & $\mathbf{H}$ \\
\hline \multirow{6}{*}{$\begin{array}{l}\text { B. VDRL } \\
\text { Tube tested }\end{array}$} & \multirow{2}{*}{ Positive Serum } & $\overline{(1)}$ & $\mathrm{NH}$ & $\mathrm{NH}$ & $\underset{\mathrm{TH}}{\mathrm{NH} \text { or }}$ & $\begin{array}{c}\mathrm{H} \text { or } \mathrm{T} \\
\text { cell }\end{array}$ & $\begin{array}{c}\mathrm{NH} \text { or } \\
\mathrm{TH}\end{array}$ & $\begin{array}{c}\mathrm{H} \text { or } \mathrm{T} \\
\text { cell }\end{array}$ & $\mathbf{H}$ & $\mathrm{H}$ & $\mathbf{H}$ & $\mathbf{H}$ \\
\hline & & $(2)$ & $\mathrm{NH}$ & $\mathrm{NH}$ & $\underset{\mathrm{TH}}{\mathrm{NH} \text { or }}$ & $\begin{array}{c}\mathrm{H} \text { or } \mathrm{T} \\
\text { cell }\end{array}$ & $\underset{\mathrm{TH}}{\mathrm{NH} \text { or }}$ & $\begin{array}{c}\mathrm{H} \text { or } \mathrm{T} \\
\text { cell }\end{array}$ & $\mathbf{H}$ & $\mathbf{H}$ & $\mathrm{H}$ & $\mathbf{H}$ \\
\hline & \multirow{2}{*}{$\begin{array}{l}\text { Negative Serum (antigen } \\
\text { serum ratio same as in } \\
\text { positive serum) }\end{array}$} & (1) & $\mathbf{H}$ & $\mathbf{H}$ & $\mathbf{H}$ & $\mathbf{H}$ & $\mathrm{H}$ & $\mathrm{H}$ & $\mathbf{H}$ & $\mathbf{H}$ & $\mathbf{H}$ & $\mathbf{H}$ \\
\hline & & (2) & $\mathbf{H}$ & $\mathbf{H}$ & $\mathbf{H}$ & $\mathbf{H}$ & $\mathbf{H}$ & $\mathbf{H}$ & $\mathbf{H}$ & $\mathbf{H}$ & $\mathbf{H}$ & $\mathbf{H}$ \\
\hline & \multirow{2}{*}{$\begin{array}{l}0.9 \text { per cent. Saline (anti- } \\
\text { gen saline ratio same as } \\
\text { in positive serum) }\end{array}$} & (1) & $\mathrm{H}$ & $\mathbf{H}$ & $\mathbf{H}$ & $\mathbf{H}$ & $\mathrm{H}$ & $\mathbf{H}$ & $\mathrm{H}$ & $\mathbf{H}$ & $\mathbf{H}$ & $\mathbf{H}$ \\
\hline & & $(2)$ & $\mathrm{H}$ & $\mathrm{H}$ & $\mathbf{H}$ & $\mathrm{H}$ & $\mathbf{H}$ & $\mathbf{H}$ & $\mathbf{H}$ & $\bar{H}$ & $\mathbf{H}$ & $\mathbf{H}$ \\
\hline \multirow{6}{*}{$\begin{array}{c}\text { C. Floccula- } \\
\text { tion tested } \\
\text { Wassermann } \\
\text { Antigen }\end{array}$} & \multirow{2}{*}{ Positive Serum } & (1) & NH & $\mathrm{NH}$ & $\underset{\mathrm{TH}}{\mathrm{NH}}$ & $\begin{array}{c}\mathrm{H} \text { or } \mathrm{T} \\
\text { cell }\end{array}$ & $\underset{\text { TH }}{\mathrm{NH}}$ & $\begin{array}{c}\mathrm{H} \text { or } \mathrm{T} \\
\text { cell }\end{array}$ & $\mathrm{H}$ & $\mathbf{H}$ & $\mathbf{H}$ & $\mathbf{H}$ \\
\hline & & $\overline{(2)}$ & NH & $\mathrm{NH}$ & $\begin{array}{c}\text { NH or } \\
\text { TH }\end{array}$ & $\begin{array}{c}\mathbf{H} \text { or } \mathrm{T} \\
\text { cell }\end{array}$ & $\begin{array}{c}\mathrm{NH} \text { or } \\
\mathrm{TH}\end{array}$ & $\begin{array}{c}\mathrm{H} \text { or } \mathrm{T} \\
\text { cell }\end{array}$ & $\mathrm{H}$ & $\mathbf{H}$ & $\mathbf{H}$ & $\mathbf{H}$ \\
\hline & \multirow{2}{*}{$\begin{array}{l}\text { Negative Serum (antigen } \\
\text { serum ratio same as in } \\
\text { positive serum) }\end{array}$} & (1) & $\mathbf{H}$ & $\mathrm{H}$ & $\mathbf{H}$ & $\mathbf{H}$ & $\mathbf{H}$ & $\mathbf{H}$ & $\mathrm{H}$ & $\mathrm{H}$ & $\mathbf{H}$ & $\mathbf{H}$ \\
\hline & & (2) & $\mathbf{H}$ & $\mathbf{H}$ & $\mathbf{H}$ & $\mathbf{H}$ & $\mathbf{H}$ & $\mathbf{H}$ & $\mathbf{H}$ & $\mathbf{H}$ & $\mathbf{H}$ & $\mathbf{H}$ \\
\hline & \multirow{2}{*}{$\begin{array}{l}0.9 \text { per cent. Saline (anti- } \\
\text { gen saline ratio same as } \\
\text { in positive serum) }\end{array}$} & (1) & $\mathbf{H}$ & $\mathrm{H}$ & $\mathbf{H}$ & $\mathbf{H}$ & $\mathrm{H}$ & $\mathrm{H}$ & $\mathrm{H}$ & $\mathrm{H}$ & $\mathbf{H}$ & $\mathbf{H}$ \\
\hline & & $\overline{(2)}$ & $\mathbf{H}$ & $\mathrm{H}$ & $\mathbf{H}$ & $\mathbf{H}$ & $\mathbf{H}$ & $\mathbf{H}$ & $\mathbf{H}$ & $\mathbf{H}$ & $\mathbf{H}$ & $\mathbf{H}$ \\
\hline
\end{tabular}

KEY : $\mathrm{NH}=$ no haemolysis. $\mathrm{H}=$ Haemolysis. $\mathrm{TH}=$ Trace of haemolysis. $\mathrm{T}$ cell $=$ more than 50 per cent. haemolysis, only a trace of cell remaining at the bottom.

(1) Optimum zone of antigen reagin proportion. (2) Gross antigen excess zone.

Regular Wassermann tests (M.R.C. No. 14) were also put up with the original sera of the above materials. The reactions were positive with syphilitic and negative with non-syphilitic sera.

\section{Experiment}

Part I.-Tube flocculation tests were put up using the positive and negative sera and 0.9 per cent. saline in the presence of gradually increasing amounts of antigen (Standard Kahn antigen, V.D.R.L. Cardiolipin antigen, and Wassermann antigen)*.

The Wassermann antigen was taken in a titre of one part of antigen to 1.1 parts of 0.85 per cent. saline. The methods of flocculation adopted were those of the Kahn standard test for flocculation with Kahn and Wassermann antigen, and of the V.D.R.L. tube test method for V.D.R.L. cardiolipin antigen. The flocculated materials were kept overnight in the cold room (at 6-8 ${ }^{\circ}$ C.). Next morning the flocculated materials from all the tubes were prepared in the following way for testing for the evidence of complement-fixing activity (C.F.A.) with and without Wassermann antigen.

The antigen-serum-saline mixtures from each tube were tested for complement-fixing activity without Wassermann antigen.

After being centrifuged at 2,500 r.p.m. for $10 \mathrm{~min}$. the

$$
\text { * Burroughs and Wellcome. }
$$

supernatant fluids from each tube were tested for C.F.A. with and without Wassermann antigen.

After passing the contents of each tube through a Seitz filter having one clarifying pad on the top of a sterilizing pad the filtrate from each was tested for C.F.A. with and without Wassermann antigen.

When the materials were tested without Wassermann antigen, they were taken in double volume to compensate for the deficient volume of antigen.

Results.-For convenience' sake the results have been shown in three groups (Table II).

(A) Kahn tested.

(B) V.D.R.L. tube tested.

(C) Flocculation tested with Wassermann antigen.

Materials from all the tubes starting from the vicinity of the optimum zone to the gross antigen excess zone, showed almost the same type of reaction. Hence only the results of the materials from the optimum zone and antigen excess zone tubes are shown. Determination of the optimum and antigen excess zones was made by observing the degree of flocculation and clarification in three or four successive tubes. 
Part 11.-After centrifuging at 2,500 r.p.m. for $10 \mathrm{~min}$. the supernatant fluids of some of the regular Wassermann tested (M.R.C. No. 14) serum antigen complement red blood cell mixtures were tested by the Kahn standard and the V.D.R.L. slide flocculation methods for evidence of reagin activity. We could not find any such evidence in any of the materials thus tested except in two specimens which showed a weak positive reaction with the V.D.R.L. slide flocculation test with neat serum only, while the Kahn flocculation and V.D.R.L. slide flocculation titres of the original sera of the same materials were more than 1 in 32 in every case. This absence of reagin activity was observed in the supernatant fluids of the tubes containing 3 M.H.D. and 5 M.H.D. of complement.

Part III.-Lastly some of the positive and negative sera were passed through the same Seitz filter as was used to filter the flocculated materials. They were then tested by the Kahn standard, V.D.R.L. slide flocculation, and Wassermann (M.C.R. No. 14) tests. It was observed that there was no evidence of any loss of reagin from the positive sera nor any new addition to the negative ones by this procedure (filtration).

\section{Discussion}

From the results of our experiments it is conclusively proved that absorption of positive syphilitic sera with lipid antigen (crude heart extract-Kahn or Wassermann antigen, or V.D.R.L. cardiolipin antigen) either by complement-fixation or by the flocculation method removes all antilipid antibody from such sera, both complement-fixing and flocculating, at the same time. The reason why the supernatant fluid of positive sera with or without Wassermann antigen partially fixed the complement, lies in the fact that although centrifuging removes the coarser precipitates, it cannot eliminate the finer antigen-antibody complexes from the media. But the failure of the same media, after filtration, to fix complement, amply proves that the antigen and reagin globulin are in fact united, so that, though the reaction is invisible, the sizes of the united antigenglobulin complexes are big enough to be retained by the filter (which cannot retain the reagin globulin of serum alone). They did not form visible floccules because at that stage they were unable to alter the stability of the media towards precipitation.

After the absorption of the reagin by the complement-fixation method, the reagin disappeared or diminished equally from the tubes containing 3 M.H.D. and 5 M.H.D. of complement (i.e. irrespective of the amount of complement fixed).

The flocculated materials of a positive serum had the same power of fixing complement as the antigen serum complex of the regular Wassermann test material of the same serum, whatever antigen was used for the former (Kahn, V.D.R.L., or W.R.).

Even large quantities of Kahn antigen (as much as $0.3 \mathrm{c} . \mathrm{ml}$.) had no anticomplementary action, as was evidenced by the constantly negative results obtained with the negative sera and saline when tested with this amount of Kahn antigen for complement-fixing power.

\section{Summary}

(1) Our results confirm the findings of Eagle (1935) that the antibody in syphilitic serum which is responsible for flocculation and complementfixation with lipid antigen is one and the same substance. Its manifestations are different in the two methods owing to different test conditions.

(2) The complement-fixation test by a particular antigen (Kahn, Wassermann, or cardiolipin) is much more sensitive than the flocculation test by the same antigen. It is suggested that the higher incidence of positive complement-fixation reactions (Rein and Kostant, 1949) in children born of syphilitic mothers is not due to the transfer of a special type of easily transmissible antibody from the mother to the child but to the fact that the quantity of reagin present in the child's serum, though insufficient to show a flocculation reaction, can none the less combine with the lipid antigen, as evidenced by the comp'ement fixing power of the antigen-reagin complex.

(3) The amount of complement fixed does not reflect the amount of antigen-reagin union. In other words, the interpretation of a strong or weak reaction on the evidence of the amount of complement fixed is fallacious, as it cannot reveal the amount of reagin present in the serum unless a quantitative procedure is adopted by varying the antigen serum ratio.

(4) Kahn antigen is at least as good as Wassermann antigen for testing complement-fixation.

(5) It is possible to detect flocculation and complement-fixation in the same material by Kahn, V.D.R.L., or Wassermann antigen.

\section{REFERENCES}

Bail, O., and Hoke, E. (1908). Arch. Hyg., 64, 313.

Bordet, J. (1898). Ann. Inst. Pasteur., 12, 688.

Dean, H. R. (1917). Lancet, 1, 45.

Eagle, H. (1935). J. Immunol., 29, 467.

, and Hogan, R. B. (1940). J. exp. Med., 71, 215.

Ehrlich, P. (1898). Dtsch. Med. Wschr., 24, 597.

- (1900). Proc. roy. Soc., 66, 424.

Landsteiner, K., and Wiener, A. S. (1940). Proc. Soc. exp. Biol., N.Y., 43, 223.

Marrack, J. R. (1938). Spec. Rep. Ser. Med. Coun. Lond., No. 230.

Nicolle, M., and Césari, E. (1922). Ann. Inst. Pasteur., 36, 463.

Puccinelli, V. (1952). British Journal of Venereal Diseases, 28, 184.

Rein, C. R. (1950). " Transactions of the International Symposium on Syphilis, Helsinki", sect. IV, p. 29 (WHO/VD/70).

, and Kostant, G. H. (1949). Arch. Derm. Syph., Chicago, 60, 217.

Topley, W. W. C., and Wilson, G. S. (1946). "Principles of Bacteriology and Immunity", rev. G. S. Wilson and A. A. Miles, 3rd ed., vol. 1, pp. 225, 233, 248, 249. Arnold, London.

Zinsser, H. (1921). J. Immunol., 6, 289. 